\title{
EFFECT of VITAMIN D INJECTION On REPRODUCTIVE PERFORMANCE of SAIDI EWES
}

\author{
M.A. Kobeisy, G. Badry, A. Ata and A. Salem \\ Animal Production Department, Faculty of Agriculture, Assiut University, Assiut, Egypt \\ mostafa_kobeisy@yahoo.com
}

\section{SUMMARY}

\begin{abstract}
A total of thirty-six Saidi pregnant ewes at late pregnancy had almost similar average body weight $(48 \mathrm{~kg})$ were divided at first before lambing into two groups control and treatment with vitamin D injection, each group 18 ewes. Ewes were assigned after lambing into 4 comparable groups (9 each) as follow, Group 1 (CC) Neither dams nor lambs treated with vitamin D, Group 2 (CT) Dams not treated, lambs treated, Group 3 (TC) Dams treated, lambs not treated and Group 4 (TT) Both dams and lambs treated. Treated ewes were injected three doses of vitamin D every week for three weeks by $500000 \mathrm{IU}$, while suckling lambs were injected vitamin D with $100000 \mathrm{IU}$ after two weeks of birth and then every month until weaning. The objective of this study was to evaluate the impact of Vitamin D injection on daily gain of lambs and some reproductive traits of ewes.
\end{abstract}

The obtained results indicate that:

1-There are a significant effect of vitamin D injection on body weight (BW) of lambs. Vitamin D injection increased $(\mathrm{P}<0.05) \mathrm{BW}$ by about $41.9,68.9$ and 99.8 in favor of $\mathrm{CT}$, TC and TT groups, respectively.

2- Vitamin D supplemented lambs born to treated-ewes increased ADG by about $96 \%$,

3- Pregnancy period of vitamin D- treated ewes was longer than that of control ones (155.95 vs. 143.65 day). Also, three doses of vitamin D injection during late pregnancy period improved fertility rates.

4-Vitamin D injection improved survival rate, while mortality rate, tended to be higher in lambs born to control ewes compared to those born to vitamin D- treated ewes.

In Conclusion, Injection of vitamin D at late pregnancy of ewes may improve reproductive performance of ewes and their lamb survival.

Keywords: Saidi sheep, lambs, vitamin D, fertility, daily gain.

\section{INTRODUCTION}

The vitamin D stimulates calcium transport by classic hormone-receptor-mediated processes (Deluca and Schnoes, 1976 and Carafoli, 1992).1, 25-D3 markedly enhances Ca ATPase mRNA concentration and activity and elevates CaBPs and their mRNA (Norman et al., 1982; Pavlovitch et al., 1983 and Zelinski et al., 1991). The active metabolite of vitamin D, 1, 25-dihydroxyvitamin D 3 [1, 25D3] is a primary regulator of calcium and phosphorus transport in the intestine. As with other steroid hormones, 1, 25-D3 binds to specific intracellular receptors, i.e., vitamin D receptors [VDR], to initiate transcription and translation of various gene products (Carafoli, 1988 and Minghetti and Norman, 1988). Furthermore, there is emerging evidence to suggest that low maternal vitamin $\mathrm{D}$ level might have imprinting effects on fetal development in many aspects (Boucher 1998; Buell et al., 2010 and McGrath et al., 2004), in addition to a role in pregnancy-related complications (Bodnar et al., 2007; Bodnar 2009; Mehta et al., 2009). In fact, the positive relationship between ewe vitamin D status and offspring birth weight needs for further investigations as recommended by Ping Zhou (2019). Also, Birdane and Avdatek (2020) concluded that different studies should be conducted to reveal the effects of vitamin A, D3, E and application on fertility parameters more clearly. Therefore, this study was conducted to examine the effect of vitamin D injection on reproductive performance of pregnant ewes. 


\section{MATERIALS AND METHODS}

The present study was carried out at the Experimental Farm of Animal Production Department, Faculty of Agriculture, Assiut University, Egypt. The objective of this study was to evaluate the impact of vitamin D injection on pregnant ewes and their lambs during suckling period.

\section{Experimental animals and design}

A total of thirty-six Saidi pregnant ewes at late pregnancy had almost similar average body weight $(48.63 \pm 1.78 \mathrm{~kg})$ were divided at first before lambing into two groups control and treatment with vitamin D injection, each group 18 ewes. Ewes were assigned after lambing into 4 comparable groups ( 9 each) as follow:

Group I (CC): Dams nor lambs treated.

Group II (CT): Dams not treated; lambs treated.

Group III (TC): Dams treated; lambs not treated.

Group IV (TT): Both dams and lambs treated.

Treated ewes were injected three doses of vitamin D every week for three weeks by 500000 IU, while suckling lambs were injected vitamin D with 100000 IU after 2 wk of birth and then every month until weaning.

\section{Management and housing}

Experimental animals were randomly assigned to two groups raised under semi open type house. Animals were weighed in the morning before feeding at the beginning of the experiment then biweekly during the experimental period and body weight change or daily gain was calculated.

All animals were fed once daily at 9.0 a.m. ad libitum wheat straw, while concentrate mixture containing $151 \mathrm{~g}$ crude protein per $\mathrm{kg}$ diet were fed to cover $60 \%$ of the requirement according to NRC (1985). Fresh water was freely available day and night. The concentrate fed mixture consist of $55 \%$ yellow corn, $22.5 \%$ wheat bran, $20 \%$ soya bean meal, $1.5 \%$ limestone, $0.5 \%$ premix and $0.5 \% \mathrm{NaCl}$. Chemical composition of concentrate feed mixture and wheat straw are shown in Table (1).

Table (1): Chemical composition of concentrate feed mixture and wheat straw on DM basis.

\begin{tabular}{lcc}
\hline Item & CFM & Wheat straw \\
\hline Dry matter (DM) & 93.01 & 94.32 \\
Organic matter (OM) & 94.79 & 88.77 \\
Crude protein (CP) & 15.10 & 2.80 \\
Crude fiber (CF) & 6.11 & 41.66 \\
Ether extract (EE) & 3.33 & 1.40 \\
Ash & 5.21 & 11.23 \\
Nitrogen free extract (NFE) & 70.25 & 42.91 \\
\hline
\end{tabular}

\section{Reproductive performance}

Lambs birth weight $(\mathrm{kg})$ were recorded, then weighted at two weeks interval for calculating daily gain. mortality rate was recorded every two weeks till weaning. The day of mating and lambing were recorded and pregnancy period was calculated. Fertility ewes was calculated from No. of lambed ewe / no. of ewes inseminated as a percentage. Also No. of fetal lambs produced / ewe inseminated and no. of total lambs produced / no. of ewe lambed were calculated.

\section{Statistical analysis}

Data were statistically analyzed according to the General Liner Model (GLM) of the SAS program (SAS, 2001) and the differences between means were detected by Duncan's Multiple Range Test (Duncan, 1955). The data were presented in mean \pm S.E Level of significance was set at $(\mathrm{P}<0.05)$. Statistical model as follow:

$$
Y i j=\mu+T i+E i j
$$


Where: $Y \mathrm{ij}=$ the observation $\mathrm{ij}, \mu=$ the overall mean, $\mathrm{Ti}=$ the effect due to treatment $\mathrm{i} ., \mathrm{Eij}=$ the experimental error.

\section{RESULTS AND DISCUSSION}

\section{Influence of vitamin D injection on lamb growth performance}

The effect of vitamin D injection on average body weight (BW) and body weight gain (ADG) of lambs are shown in Table (2) and Figs. $(1,2)$. There are a significant effect of vitamin D injection on body weight $(\mathrm{BW})$ of lambs, vitamin $\mathrm{D}$ injection increased $(\mathrm{P}<0.05)$ final BW $(\mathrm{W} 11)$ by about 41.9, 68.9 and $99.8 \%$ in favor of CT, TC and TT groups, respectively. Generally, the average body weight of lambs recorded the highest values in T.T followed by T.C. While, that of the C.T and C.C group lambs recorded the lowest ones. Such improvement was due to the effect of vitamin D on bone health and variety of organ systems beyond the skeleton (Richel et al., 1989).

Table (2): Live body weight $(\mathrm{kg})$ of growing ram lambs as influenced by vitamin D injection.

\begin{tabular}{|c|c|c|c|c|}
\hline \multirow{2}{*}{ Age / week } & \multicolumn{4}{|c|}{ Treatment } \\
\hline & C.C & C.T & T.C & T.T \\
\hline W 1 & $2.22 \pm 0.26^{b}$ & $3.16 \pm 0.32^{\mathrm{a}}$ & $3.50 \pm 0.28^{\mathrm{a}}$ & $3.89 \pm 0.34^{\mathrm{a}}$ \\
\hline W 2 & $4.07 \pm 0.42^{b}$ & $5.74 \pm 0.55^{\mathrm{a}}$ & $6.10 \pm 0.18^{a}$ & $6.18 \pm 0.55^{\mathrm{a}}$ \\
\hline W 3 & $5.44 \pm 0.49^{\mathrm{b}}$ & $7.46 \pm 0.27^{\mathrm{a}}$ & $7.95 \pm 0.38^{a}$ & $8.41 \pm 0.44^{\mathrm{a}}$ \\
\hline W 4 & $6.42 \pm 0.64$ & $9.09 \pm 0.44$ & $9.38 \pm 0.75$ & $9.10 \pm 1.38$ \\
\hline W 5 & $7.49 \pm 0.45$ & $10.46 \pm 0.32$ & $10.53 \pm 1.16$ & $10.07 \pm 2.15$ \\
\hline W 6 & $7.49 \pm 0.44^{b}$ & $10.73 \pm 0.52^{\mathrm{ab}}$ & $11.35 \pm 1.35^{\mathrm{ab}}$ & $12.81 \pm 0.20^{\mathrm{a}}$ \\
\hline W 7 & $7.92 \pm 0.22^{b}$ & $10.50 \pm 0.85^{\mathrm{ab}}$ & $11.26 \pm 1.38^{\mathrm{ab}}$ & $13.34 \pm 0.21^{\mathrm{a}}$ \\
\hline W 8 & $8.73 \pm 0.470^{b}$ & $10.96 \pm 1.08^{\mathrm{ab}}$ & $11.51 \pm 1.48^{\mathrm{ab}}$ & $14.51 \pm 0.09^{a}$ \\
\hline W 9 & $8.24 \pm 0.44^{\mathrm{c}}$ & $10.90 \pm 1.08^{\mathrm{ab}}$ & $12.98 \pm 0.97^{\mathrm{b}}$ & $14.78 \pm 0.82^{a}$ \\
\hline W 10 & $8.70 \pm 0.76^{b}$ & $11.26 \pm 1.15^{\mathrm{ab}}$ & $14.04 \pm 0.1 .21^{\mathrm{ab}}$ & $14.77 \pm 29^{a}$ \\
\hline W 11 & $8.28 \pm 0.32^{b}$ & $11.74 \pm 1.73^{\mathrm{ab}}$ & $13.73 \pm 0.1 .80^{\mathrm{ab}}$ & $16.00 \pm 2.03^{a}$ \\
\hline ADG(g/day) & $78.7 \pm 7.34^{\mathrm{b}}$ & $111.4 \pm 6.30^{\mathrm{ab}}$ & $132.9 \pm 17.46^{\mathrm{ab}}$ & $157.3 \pm 1.96^{\mathrm{a}}$ \\
\hline
\end{tabular}

There were significant differences in ADG of growing lambs among groups, but the highest values of ADG was recorded in T.T followed by T.C. While, that of the C.C and C.T group lambs recorded the lowest ones, vitamin D supplemented lambs born to treated-ewes increased ADG by about $96 \%$, the corresponding values for control lambs born to vitamin D-treated ewes and treated lambs born to control ewes were 64 and 55\%, respectively (Table 2 \& Fig. 2). Ping Zhou et al. found that concentrations of $25(\mathrm{OH}) \mathrm{D} 3$ and $25(\mathrm{OH}) \mathrm{D}$ were positively associated with subsequent birth weights of singleton and of twin lamb litters. However, Curran and Crowley (1961) indicate that no significant difference in live weight gains of lambs between control and treated lambs, which injected with 200,000 IU of Vitamin D3. Also, Montgomery et al. (2001) reported that vitamin D3 supplementation had no effect on final weight of Crossbred steers. In addition, Joe (2005) found that body weights or body weight gain of Rambouillet lambs were not significantly $(\mathrm{P}>0.05)$ affected by injecting of vitamin D at days 14 and 42 after birth.

\section{Effect of vitamin D injection on some reproductive traits and survival rate}

The obtained results of Table (3) and Figs. (3) are shown that pregnancy period of vitamin Dtreated ewes was longer than that of control ones (155.95 vs. 143.65 day). Also, three doses of vitamin $\mathrm{D}$ injection during late pregnancy period improved fertility rate as measured by no of lambed ewes/no of ewes inseminated and no of total lambs produced/ ewe inseminated and twinning rate as measured by no of total lambs produced/ewe lambed. Similar results were found by Handel et al. (2016), they observed a very strong relationship between total $25(\mathrm{OH}) \mathrm{D}$ concentrations in summer and a ewe's fecundity the following spring. Also, Vitamin D injection improved survival rate, mortality rate tended to be higher in lambs born to control ewes compared to those born to vitamin $\mathrm{D}$ - treated. ewes (17 vs. $15 \%$ ) and this may be related to the improvement of $\mathrm{IgG}$ concentration of colostrum, or birth weight, which supported by Handel et al. (2016), they found a positive association between total 25(OH)D and 
the number of lambs produced that survived their first year of life, an important component of female reproductive fitness.

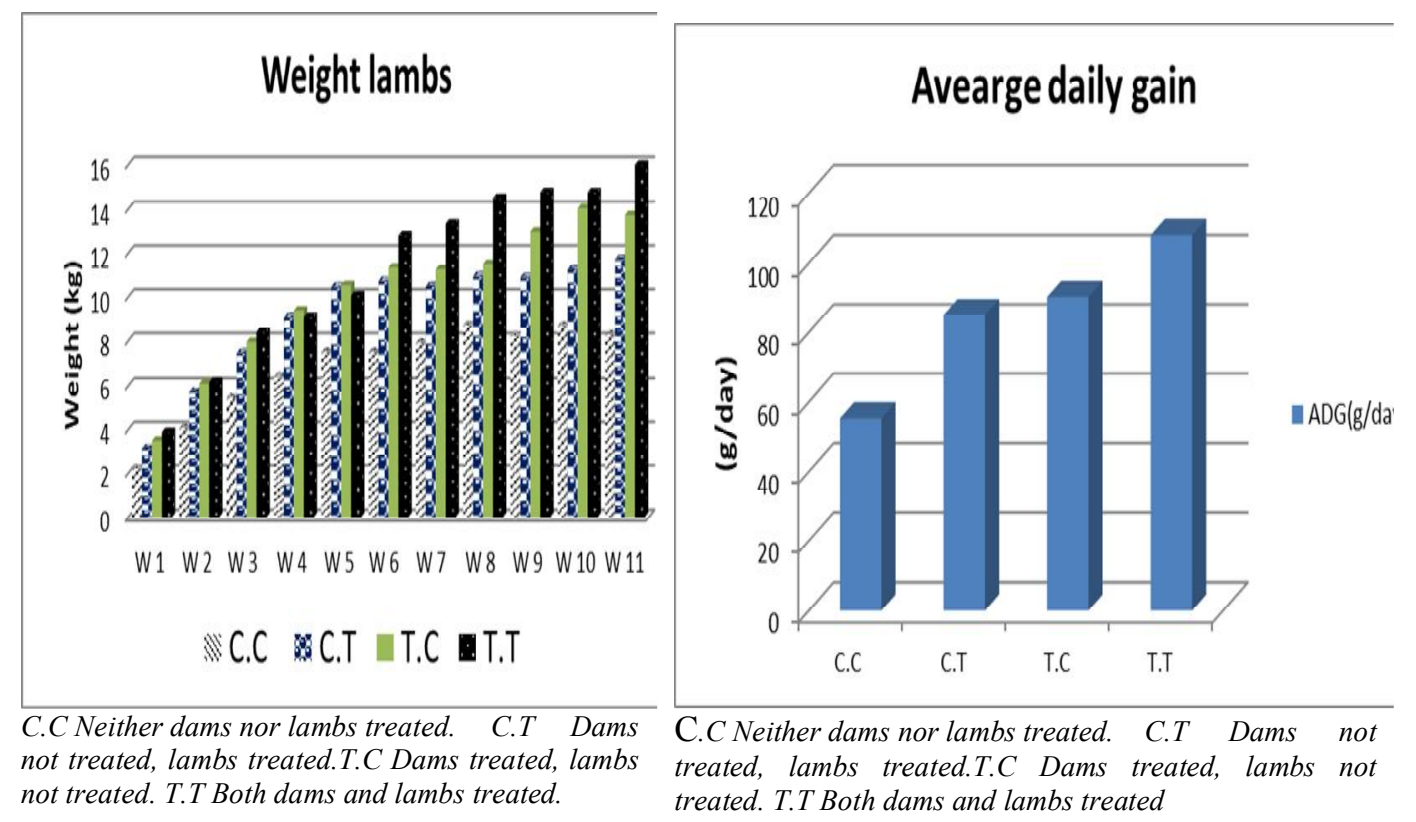

Fig. (1): Effect of vitamin D injection on lambs body weight.

Fig. (2): Effect of vitamin D injection on lambs average daily gain.

Table (3): Effect of vitamin D injection on some reproductive traits and lamb mortality rate.

\begin{tabular}{lcc}
\hline Item & Control (C) & Treatment (T) \\
\hline Pregnancy period (day) & 143.65 & 155.95 \\
Fertility, no. of lambed ewes/no. of ewes inseminated (\%) & 52.77 & 72.22 \\
No. of total lambs produced/ ewe inseminated (\%) & 0.66 & 1.11 \\
No. of total lambs produced/ewe lambed (\%) (twinning rate) & 1.09 & 1.53 \\
Mortality rate of lambs (\%) & 17 & 15 \\
\hline C:
\end{tabular}

$C$ : control ewes. T: vitamin D-treated ewes, ewes were injected three doses of vitamin D every week for three weeks by $500000 \mathrm{IU}$ during late pregnancy.

Karras et al. (2016) reported that low maternal vitamin D levels during pregnancy have been associated with a plethora of adverse neonatal outcomes, including small for gestational age and preterm births, detrimental effect on off spring bone and risk of infectious diseases. Also, they found that no results are yet available regarding the potential long-term side effects of vitamin D supplementation on neonatal health, thus further high-quality research is needed in order to follow up the health of offspring of mothers supplemented with vitamin D during pregnancy. In the same trend Lockwood et al. (2016) found that supplementation of Merino ewes with cholecalciferol in late pregnancy improved the Vitamin D status of ewes and lambs at birth. On the other hand, lamb birth weight is the greatest contributor to lamb survival however, even when birth weights are optimized, lamb survival to weaning rarely exceeds $90 \%$ for singles, $75 \%$ for multiples and $60 \%$ for triplets (Oldham et al., 2011; Hinch and Brien 2014), suggesting that factors independent of birth weight must also influence lamb survival. Immune competency has been linked to survival in other neonatal mammals (Merlot et al., 2013), however its role in the mortality of lambs is poorly understood. Increased vitamin D levels in ewes and neonatal lambs may therefore be associated with a greater ability to control infection and/or limit infection-driven inflammation, and thus may contribute to improved lamb survival. 

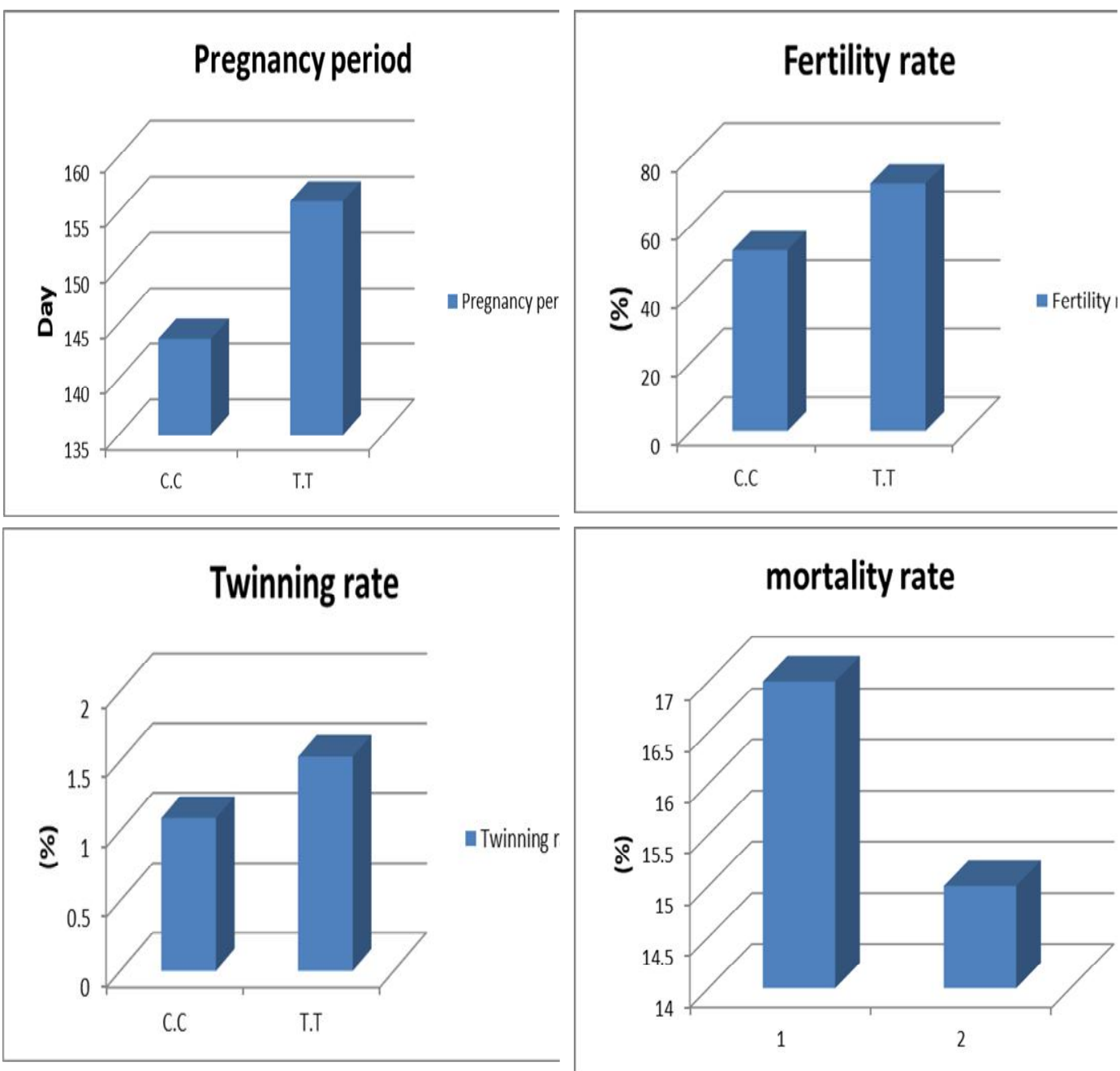

CC 11: control ewes. TT/2: vitamin D-treated ewes, ewes were injected three doses of vitamin D every week for three weeks by 500000 IU during late pregnancy.

Fig 3. Some reproductive traits of Saidi ewes injected with vitamin D.

\section{CONCLUSION}

Injection of vitamin D at late pregnancy of ewes and lambs during suckling period may improve productive and reproductive performance of ewes and their lamb survival.

\section{REFERANCES}

Birdane, M.K. and F. Avdatek (2020). Effect of vitamin A, D3, E treatment on fertility in the Prrlak sheep. Kocatepe Veterinary Journal, 13(2):179-184.

Bodnar, L.M. (2009). Maternal vitamin D deficiency is associated with bacterial vaginosis in the first trimester of pregnancy. J Nutr., 139(6):1157 61.

Bodnar, L.M., J.M. Catov, H.N. Simhan, M.F. Holick, R.W. Powers and J.M. Roberts, (2007). Maternal Vitamin D deficiency increases the risk of preeclampsia. J Clin. Endocrinol. Metab, 92(9):3517-22.

Boucher, B.J. (1998). Inadequate vitamin D status: does it contribute to the disorders comprising syndrome ' $X$ '?. British Journal of Nutrition, 79(4): 315-327. 
Buell, J.S., B. Dawson-Hughes, T.M. Scott, D.E. Weiner, G.E. Dallal, W.Q. Qui and R.A. Bhadelia (2010). 25-Hydroxyvitamin D, dementia, and cerebrovascular pathology in elders receiving home services. Neurology, 74(1): 18-26.

Carafoli, E. (1988). Membrane transport of calcium: An overview. In Methods in Enzymology, Vol. 157, pp. 3-11. Academic Press.

Carafoli, E. (1992). The Ca2+ pump of the plasma membrane. Journal of Biological Chemistry, 267(4), $2115-2118$

Curran, S. and J. P. Crowley (1961). Supplementary Vitamin $\mathrm{D}_{3}$ for Lambs. Irish Journal of Agricultural Research , 1(1): 43-48.

DeLuca, H.F., and H.K. Schnoes (1976). Metabolism and mechanism of action of vitamin D. Annual review of biochemistry, 45(1): 631-666.

Handel,I. K. Watt, G. Pikington, J. Pemberton, A. Macrae, P. Scott, T. McNeilly, J. Barry, D. Clements, D. Nusseyand, R. Mellanby (2016). Vitamin D status predicts reproductive fitness in wild sheep population. Sci. Rep., 6, https://do,org/10.1038/Srep 18986.

Hinch, G.N., and F. Brien (2014). Lamb survival in Australian flocks: a review. Animal Production Science, 54(6), 656-666.

Joe M.S. (2005). Vitamin d supplementation in fall born Rambouillet lambs raised on small grain pastures. M.Sc. Thesis, Faculty of the Graduate School of Angelo State University, Texas.

Karras S.N., H. Fakhoury, G. Muscogiuri, W.B. Grant, J.M. van den Ouweland, A.M. Colao and K. Kotsa (2016). Maternal vitamin D levels during pregnancy and neonatal health: evidence to date and clinical implications. Ther. Adv. Musculoskel. Dis., 8(4): 124-135.

Lockwood, A., A. Currie, S. Hancock, S. Broomfield, S. Liu, V. Scanlan and A.N. Thompson (2016). Supplementation of Merino ewes with cholecalciferol in late pregnancy improves the vitamin D status of ewes and lambs at birth but is not correlated with an improvement in immune function in lambs. Animal production science, 56(4): 757-766.

Mehta, S., D.J. Hunter, F.M. Mugusi, D. Spiegelman, K.P. Manji, E.L. Giovannucci, and W.W. Fawzi (2009). Perinatal outcomes, including mother-to-child transmission of HIV, and child mortality and their association with maternal vitamin D status in Tanzania. The Journal of infectious diseases, 200(7), 1022-1030.

Mellanby, E. (1919). An experimental investigation of rickets. Lancet, 1: 407-412.

Merlot, A.M., D.S. Kalinowski and D.R. Richardson (2013). Novel chelators for cancer treatment: where are we now?. Antioxidants \& Redox Signaling, 18(8): 973-1006.

Minghetti, P.P. and A.W.L. Norman (1988). 1, $25(\mathrm{OH})$ 2-vitamin D3 receptors: gene regulation and genetic circuitry. The FASEB Journal, 2(15): 3043-3053.

Montgomery, J.L., M.A. Carr, C.R. Kerth, G.G. Hilton, B.P. Price, M.L. Galyean, R.L. Horst and M.F. Miller (2001). Effect of vitamin D3 supplementation level on the postmortem tenderization of beef from steers. J. Anim, Sci., 80: 971-981.

Norman, A.W., J. Roth and L. Orci (1982). The vitamin D endocrine system: steroid metabolism, hormone receptors, and biological response (calcium binding proteins). Endocrine Reviews, 3(4): 331-366.

NRC (1985). Nutritional Requirements of Sheep. 6th rev. ed. Natl. Acad. Press, Washington, DC.

Oldham C.M., A.N. Thompson, M.B. Ferguson, D.J. Gordon G.A. Kearney and B.L. Paganoni (2011). The birth weight and survival of Merino lambs can be predicted from the profile of liveweight change of their mothers during pregnancy. Animal Production Science, 51:776-783.

Pavlovitch, J.H., L. Didierjean, M. Rizk, S. Balsan, and J.H. Saurat (1983). Skin calcium-binding protein: distribution in other tissues. American Journal of Physiology-Cell Physiology, 244(1): C50-C57.

Zhou P., G. Thomas, McEvoy, Andrew C. Gill, Nicola R. Lambe, Claire R. Morgan-Davies, Emma Hurst, Neil D. Sargison \& Richard J. Mellanby,2019, Investigation of relationship between vitamin 
D status and reproductive fitness in Scottish hill sheep, Scientific Reports volume 9, Article number: 1162 (2019) .

Rickel, J.W. (1989). Intelligent computer-aided instruction: A survey organized around system components. IEEE Transactions on Systems, Man, and Cybernetics, 19(1): 40-57.

SAS (2001). SAS/STAT guide for personal computer (Version 8.2 End). SAS INST, Cary, N.C, 1987.

Zelinski, J.M., D.E. Sykes and M.M. Weiser (1991). The effect of vitamin D on rat intestinal plasma membrane Ca-pump mRNA. Biochemical and Biophysical Research Communications, 179(2): 749-755.

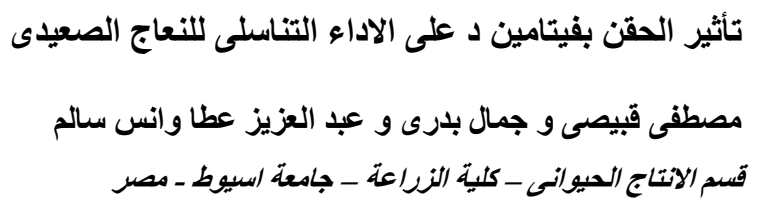

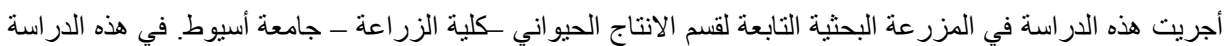

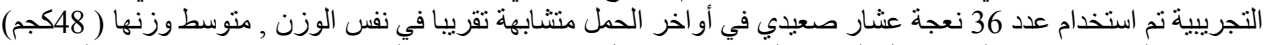

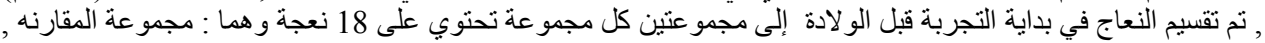

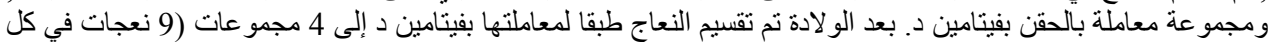

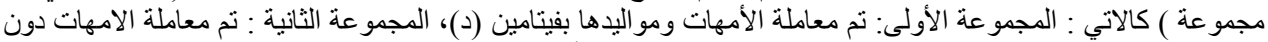

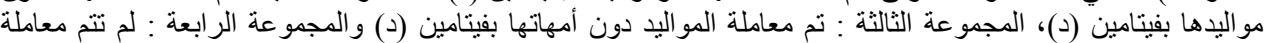

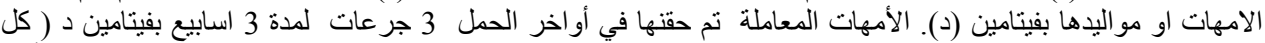

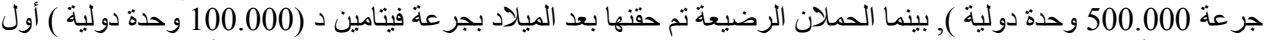

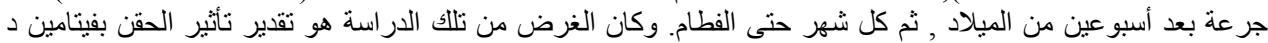

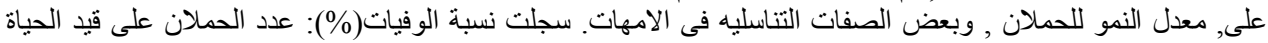
منسوبة الى عدد الحملان المولودة الكلية ولنية وتم حسابه كل

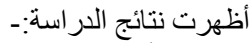

1- وجد هناك تأثير معنوي للحقن بفيتأكين د د على وزن الحملان وتقدر نسبة الزيادة في الوزن بحو الي 41.9 و 68.9 و 99.85

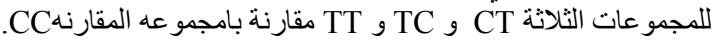

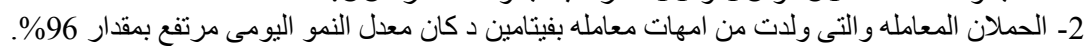

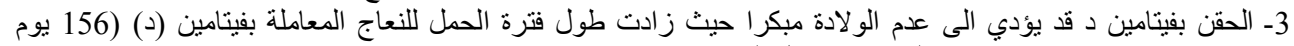

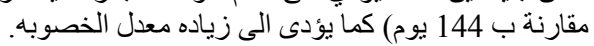

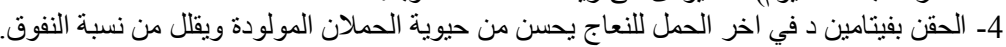

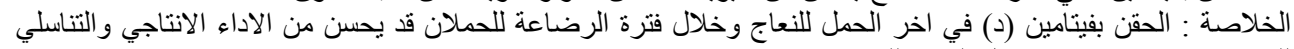
اللنعاج وحيوية و انخفاض معدل النفوق للحملان. 